\title{
CHAPTER SELECTING TROPICAL AND SUBTROPICAL 9 TREE SPECIES FOR WIND RESISTANCE
}

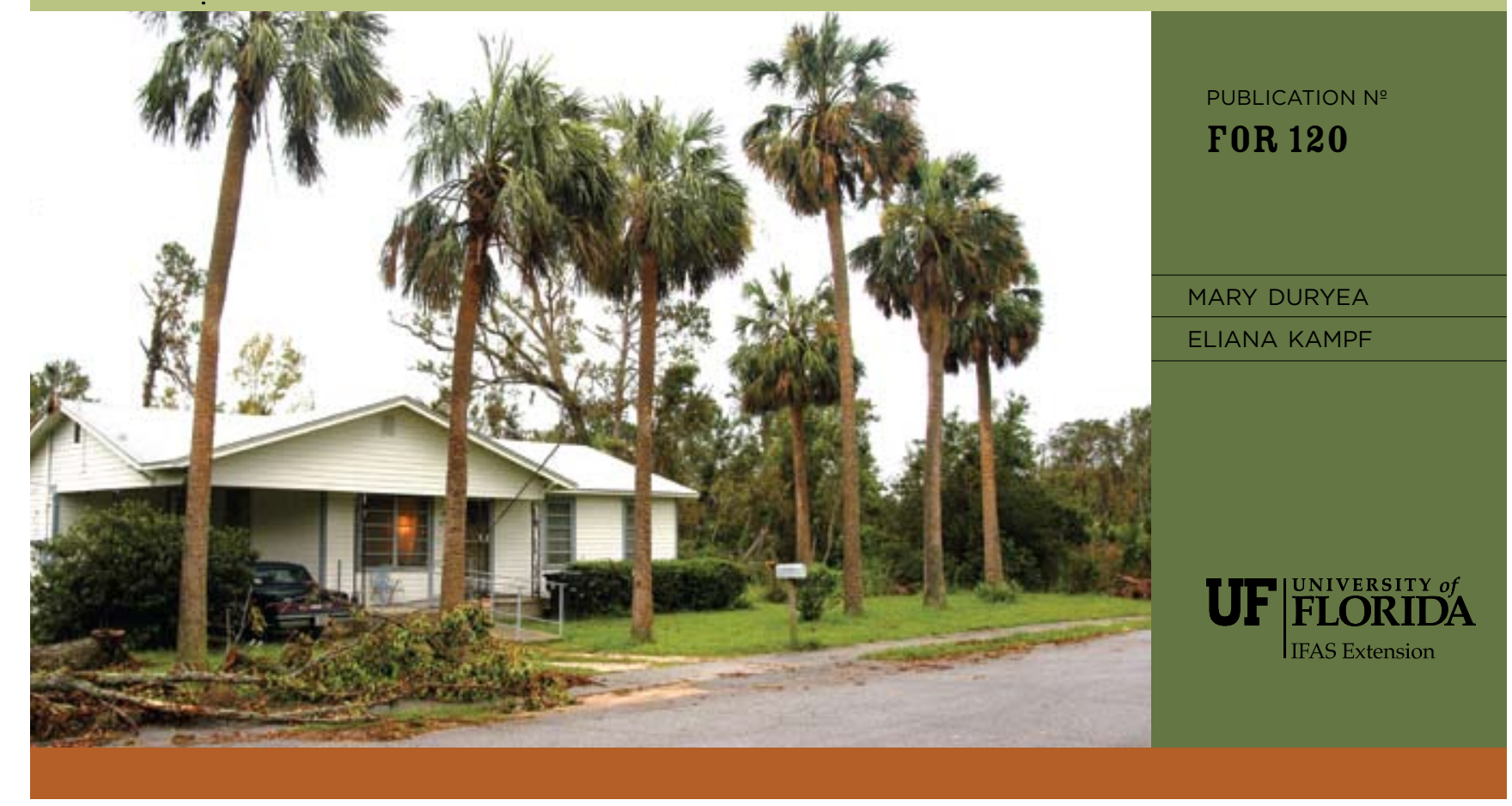

\section{Introduction}

A team of scientists at the University of Florida/Institute of Food and Agricultural Sciences (UF/IFAS) has been tracking and studying major hurricanes since Hurricane Andrew in 1992 to determine their effect on the urban forest. One of the major goals of this study is to assemble lists of relative wind resistance for different urban tree species. These lists can assist communities to better prepare for the next hurricane season and to rebuild a healthy urban forest by selecting proper species.

This fact sheet presents the research and methodology that lead to lists of relative wind resistance for tropical and subtropical tree species (Chapter 8 reports on coastal plain tree species). It also discusses in detail its results and additional recommendations for selecting and establishing tropical and subtropical species for a healthier and more wind-resistant urban forest.

\begin{tabular}{|c|l|c|}
\hline \multicolumn{2}{|c|}{ Contents } \\
\hline$I$ & Study & p. 1 \\
\hline$I I$ & Methods & p. 2 \\
\hline$I I \mid$ & Results & p. 2 \\
\hline$I V$ & Recommendations & p. 11 \\
\hline
\end{tabular}

\section{Study}

Since 1992 when Hurricane Andrew struck south Florida, we have been studying the impacts of hurricanes on urban forests (Duryea et al. 1996; Duryea et al. 2007a; Duryea et al. 2007b). In 1998 when Hurricane Georges (177 km/h) crossed over the entire island of Puerto Rico, and in 2004 when Hurricanes Jeanne $(193 \mathrm{~km} / \mathrm{h}$ ) and Charley (233 $\mathrm{km} / \mathrm{h}$ ) struck south Florida, we continued with these measurements. Hurricanes striking the subtropical and tropical regions of Florida and Puerto Rico, with their varied wind speeds, gave us the opportunity to study over sixty species and their comparable responses to wind. This study utilizes our results from hurricanes and incorporates results from a survey and the scientific literature to present lists of relative wind resistance for tropical and subtropical tree species. 


\section{Methods}

Urban tree damage was measured within 3 to 10 days of the two hurricanes that struck Florida (Charley and Jeanne 2004) and the one that struck Puerto Rico (Georges 1998). In this study we also included the hurricane response of some tropical/subtropical species, such as live oak (Quercus virginiana) and sabal palm (Sabal palmetto), that occur throughout Florida and were impacted by Hurricanes Erin (1995), Opal (1995), and Ivan (2004) in the Florida panhandle (Figure 1).

Hurricane Andrew measurements involved a survey of 128 homeowners in Dade County, Florida who measured and reported to us about each tree in their yards (Duryea et al. 1996). The methodology for the other hurricanes was the same and is as follows: neighborhoods at the point of landfall of the hurricane were randomly chosen. For each neighborhood, all trees were observed along street transects. For each of the three hurricanes, we sampled 26 neighborhoods and 3,678 trees (Georges), 17 neighborhoods and 2,272 trees (Charley), and 7 neighborhoods and 1,642 trees (Jeanne). (Branch loss measurements for Hurricanes Frances [2005] and Jeanne were combined and made immediately following Hurricane Jeanne.)

\begin{tabular}{|l|c:l|}
\hline \multicolumn{2}{|l|}{ FOR MORE INFORMATION " } \\
\hline ON THE URBAN TREE & $\mathrm{CH}$ & Selecting Southeastern Coastal \\
MEASUREMENT AND SURVEY & $\mathbf{8}$ & $\begin{array}{l}\text { Plain Tree Species for Wind } \\
\text { METHODS }\end{array}$ \\
\hline
\end{tabular}

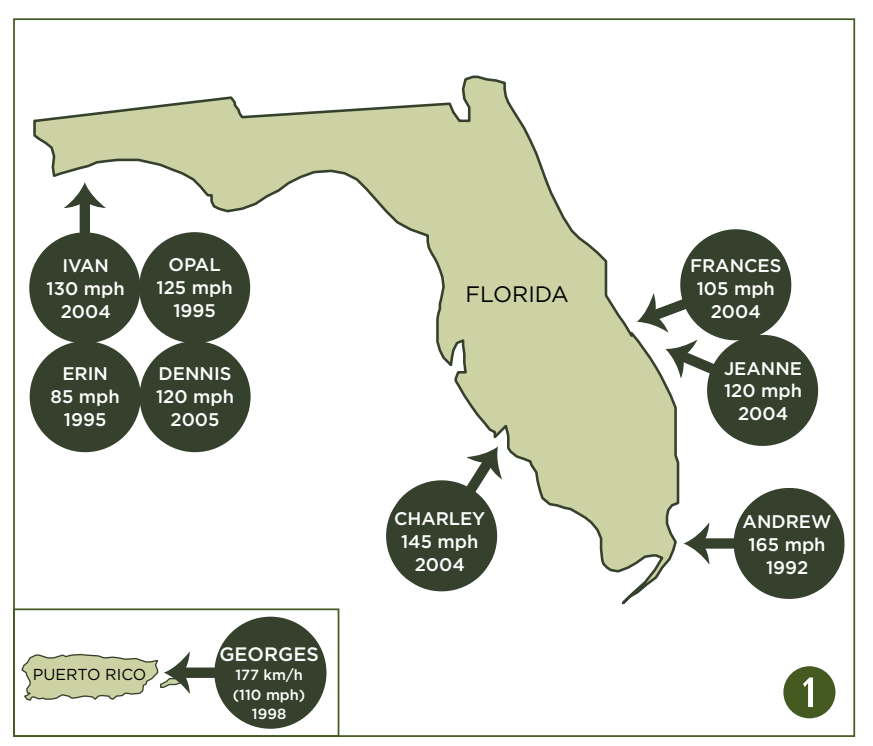

Figure 1

Urban trees were measured following hurricanes striking Florida and Puerto Rico. For each hurricane, the arrow points to the location of landfall. The maximum sustained wind speed (mph) and year are included.

\section{Results}

\section{Overall Urban Forest Loss}

The percent of urban forest loss (mortality) ranged from $13 \%$ for hurricane Georges to $16 \%$ for hurricane Jeanne to $18 \%$ for hurricane Charley. The urban forest loss for these hurricanes combined with hurricanes striking the southeastern coastal plain is reported in Chapter 5-Lessons Learned from Hurricanes. To evaluate tree survival and responses, we divided the species into four categories: palms, dicots, conifers, and Puerto Rico species. We then talk about native versus exotic species.

Tree Survival and Branch Loss

\section{Palms}

Of the palms, sabal palm along with the smaller palms such as areca (Chrysalidocarpus lutescens), Manila (Veitchia merrilii) and pigmy date (Phoenix roebelenii) had $89 \%$ or greater survival (Table 1). In Hurricane Charley, palm survival was $88 \%$ compared to $77 \%$ for all other tree species $(\mathrm{p}=0.0001)$. In Hurricane Jeanne, palm survival was $86 \%$ versus $76 \%$ for all other tree species $(\mathrm{p}<0.0001)$. When compared to dicots, palms have often been observed to be more resistant to winds (Francis and Gillespie 1993; Frangi and Lugo 1991). Zimmerman et al. (1994) conclude that palms are wind resistant because they are able to lose all their leaves without losing their terminal meristem. Coconut palm (Cocos nucifera), which survived poorly in Hurricane Andrew (Duryea et al. 1996), exhibited intermediate survival in both Charley's and Georges' winds (77\% survival) (Table 1). Royal palm (Roystonea elata) which had only $63 \%$ survival in Andrew, had improved survival (87\%) in Hurricane Charley on the deeper soils of the Gulf Coast. Washington palm (Washingtonia robusta) survived well in Charley's $233 \mathrm{~km} / \mathrm{h}$ (145 mph) winds ( $92 \%$ ) but less well in Jeanne's winds of $193 \mathrm{~km} / \mathrm{h}$ (120 mph) (80\%). This was perplexing to us until we looked at the height comparisons of the two populations. Washington palms in the Ft. Pierce area that experienced Hurricane Jeanne averaged $11 \mathrm{~m}$ in height with $42 \%$ of the palms above 10 $\mathrm{m}$ compared to an average of $4 \mathrm{~m}$ and only $7 \%$ over $10 \mathrm{~m}$ for Charley; perhaps as Washington palms acquire their heights of 20 meters and above, their wind resistance starts to plummet. 
Table 1. Survival of tropical and subtropical tree species after four hurricanes.*

\begin{tabular}{|c|c|c|c|c|}
\hline \multirow{2}{*}{ Tree Species } & \multicolumn{4}{|c|}{$\begin{array}{l}\text { Survival (\%) After Each Hurricane } \\
\text { (Wind Speed in km/h; mph) }\end{array}$} \\
\hline & $\begin{array}{c}\text { Georges } \\
(177 \mathrm{~km} / \mathrm{h} ; 110 \mathrm{mph})\end{array}$ & $\begin{array}{c}\text { Jeanne } \\
(193 \mathrm{~km} / \mathrm{h} ; 120 \mathrm{mph})\end{array}$ & $\begin{array}{c}\text { Charley } \\
(233 \mathrm{~km} / \mathrm{h} ; 145 \mathrm{mph})\end{array}$ & $\begin{array}{c}\text { Andrew } \\
(265 \mathrm{~km} / \mathrm{h} ; 165 \mathrm{mph})\end{array}$ \\
\hline \multicolumn{5}{|l|}{ Dicots } \\
\hline Araucaria heterophylla & 88 & - & 74 & - \\
\hline Bucida buceras & 84 & - & 57 & 68 \\
\hline Bursera simarouba & - & - & 89 & 84 \\
\hline Callistemon viminalle & - & - & - & 52 \\
\hline Carya floridana & - & 83 & - & - \\
\hline Casuarina equisitifolia a & - & - & 57 & 4 \\
\hline Cinnamomum camphora b & - & - & 90 & - \\
\hline Citrus spp. & - & 67 & 74 & 25 to 66 \\
\hline Coccoloba uvifera & - & - & 84 & 64 \\
\hline Delonix regia C (in S. FL) & 94 & - & - & 57 \\
\hline Eugenia foetida & - & - & - & 96 \\
\hline Ficus aurea & - & - & 84 & - \\
\hline Mangifera indica & 76 & - & - & 60 \\
\hline Melaleuca quinquenervia a & 65 & 75 & 45 & 79 \\
\hline Persea americana & - & - & - & 46 \\
\hline Quercus geminata & - & 94 & - & - \\
\hline Quercus laurifolia & - & 94 & 86 & - \\
\hline Quercus virginiana & - & 97 & 78 & 78 \\
\hline Schefflera actinophyla b (in C. and S. FL) & 87 & - & - & 85 \\
\hline Swietenia mahagoni & 92 & - & - & 75 \\
\hline Tabebuia heterophylla & 83 & - & - & 72 \\
\hline \multicolumn{5}{|l|}{ Monocots - Palms } \\
\hline Chrysalidocarpus lutescens & 94 & - & 97 & 93 \\
\hline Cocos nucifera & 77 & - & 77 & 41 \\
\hline Phoenix reclinata $\mathrm{b}$ (in $\mathrm{S}$. $\mathrm{FL}$ ) & - & - & 100 & - \\
\hline Phoenix roebelenii & - & 100 & 100 & - \\
\hline Roystonea elata ( $R$. borinquena in PR) & 93 & - & 87 & 63 \\
\hline Sabal palmetto & - & 92 & 92 & 93 \\
\hline Syagrus romanzoffiana c (in S. FL) & - & 74 & 69 & 42 \\
\hline Veitchia merrilii & 89 & - & 95 & - \\
\hline Washingtonia robusta & - & 80 & 92 & - \\
\hline \multicolumn{5}{|l|}{ Conifers } \\
\hline Pinus clausa & - & 4 & - & - \\
\hline Pinus elliottii var. densa ( $P$. caribaea in PR) & 89 & 90 & 79 & 73 \\
\hline Pinus palustris & - & - & 57 & - \\
\hline Taxodium distichum & - & - & 95 & - \\
\hline $\begin{array}{l}\text { Prohibited from use in Florida } \\
\text { Invasive and not recommended for use in Floric } \\
\text { Caution: may be used but must be managed to } \\
\text { Survival is defined as the percentage of trees st } \\
\text { size greater than } 20 \text { trees for each hurricane. Le } \\
\text { Charley; Andrew survival percentages are from }\end{array}$ & $\begin{array}{l}\text { orevent escape in Floric } \\
\text { I standing after the hur } \\
\text { st Significant Differenc } \\
\text { uryea et al. } 1996 .\end{array}$ & $\begin{array}{l}\text { da (Fox et al. 2005) } \\
\text { ricane. Numbers are on } \\
\text { es at } p=0.05 \text { are } 16 \% \mathrm{fo}\end{array}$ & $\begin{array}{l}\text { Iy presented for tree sp } \\
\text { or Georges, 35\% for Jea }\end{array}$ & $\begin{array}{l}\text { ecies having a sample } \\
\text { nne, and } 30 \% \text { for }\end{array}$ \\
\hline
\end{tabular}




\section{Dicots}

Of the dicot tree species, the poorest surviving species were melaleuca (Melaleuca quinquenervia), Australian pine (Casuarina equisitifolia), and black olive (Bucida buceras) in Hurricane Charley. Dicots with highest survival were camphor (Cinnamomum camphora), gumbo limbo (Bursera simarouba), sea grape (Coccoloba uvifera), strangler fig (Ficus aurea), live oak, and laurel oak (Quercus laurifolia) (Figure 2).

Trees with large amounts of branch loss in a hurricane (Figure 3) may not be considered as healthy urban trees, so we re-analyzed survival taking into account branches lost. Standing trees with $50 \%$ or greater branch loss were called dead and a "new" survival was calculated (named "recalculated survival").

Some species such as camphor, strangler fig, laurel oak, and live oak may continue to stand in hurricaneforce winds but at the same time lose large branches, especially at the $233 \mathrm{~km} / \mathrm{h}(145 \mathrm{mph})$ winds of Charley (Figure 4).

After intermediate survival in Hurricane Andrew, West Indian mahogany (Swietenia mahagoni) and white cedar (Tabebuia heterophylla) exhibited higher survival in Hurricane Georges at $177 \mathrm{~km} / \mathrm{h}$ (110 mph). After relatively poor survival in Andrew, 94\% of the royal poinciana (Delonix regia) survived the relatively lighter winds of Hurricane Georges. In a study of 24 species of urban trees in San Juan, PR after Hurricane Georges, species with the highest survival (lowest failed stems) were West Indian mahogany (100\%), mango (Mangifera indica) (98\%), queen's crape myrtle (Lagerstroemia speciosa) (98\%), and royal poinciana (98\%) (Francis 2000). Species with the poorest survival were African tuliptree (Spathodea campanulata) (66\%) and weeping banyan (Ficus benjamina) (70\%) (Francis 2000). Studies summarized in Everham and Brokaw's table of species resistance to catastrophic wind (1996) rank gumbo limbo, mahogany, sea grape, baldcypress (Taxodium distichum), live oak, and white cedar with high wind resistance in at least two or more studies. Species that received the lowest wind resistance ratings in two or more studies were Australian pine (Casuarina equisetifolia), Honduras mahogany (Swietenia macrophylla), swamp mahogany (Eucalyptus robusta), and Caribbean pine (Pinus caribaea).

In the urban areas of the southeastern coastal plain, laurel oak trees did not survive as well as live oak and sand live oak (Quercus geminata) in four hurricanes (Duryea et al. 2007b) (See Chapter 8-Selecting Southeastern Coastal Plain Tree Species for

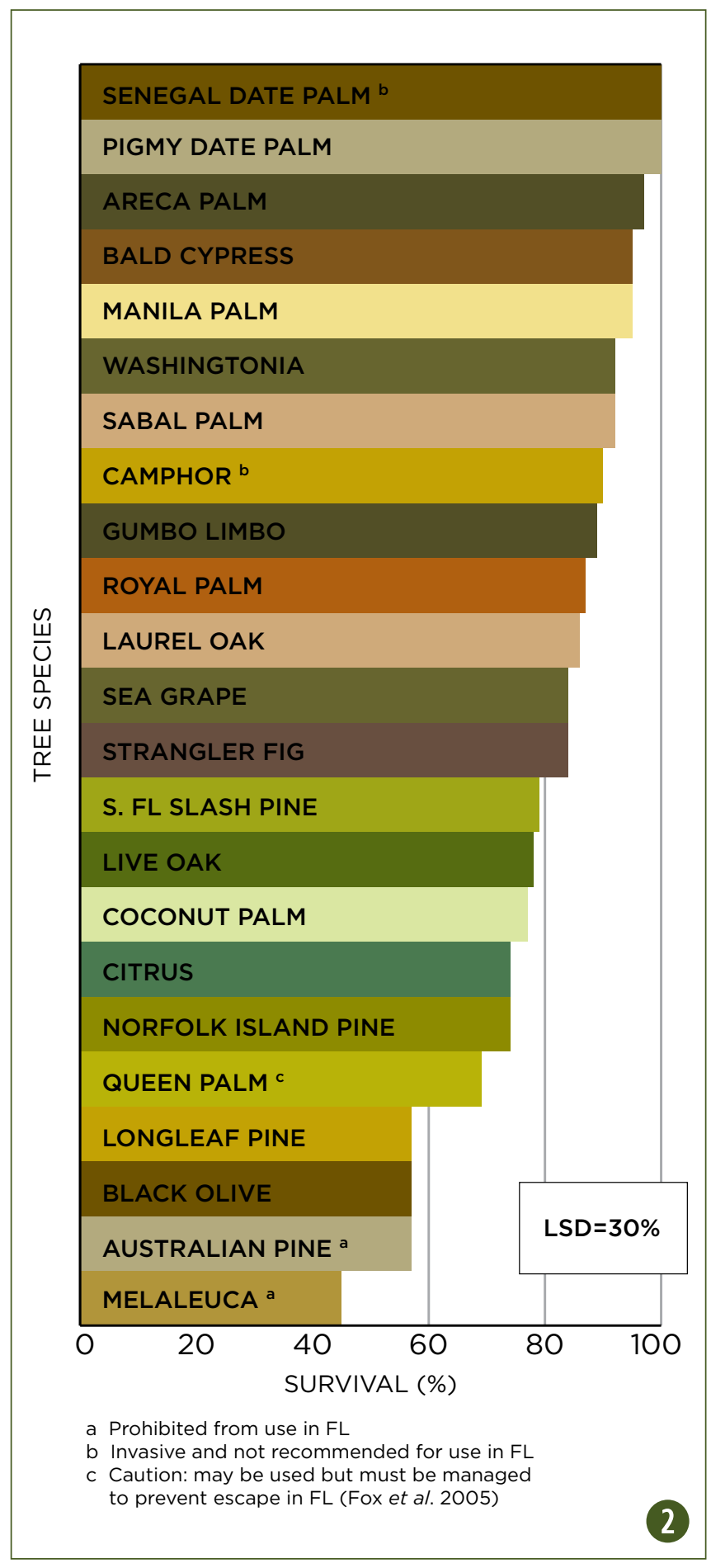

\section{Figure 2}

Survival (\%) of tree species in Hurricane Charley which struck at $233 \mathrm{~km} / \mathrm{h}(145 \mathrm{mph})$. 


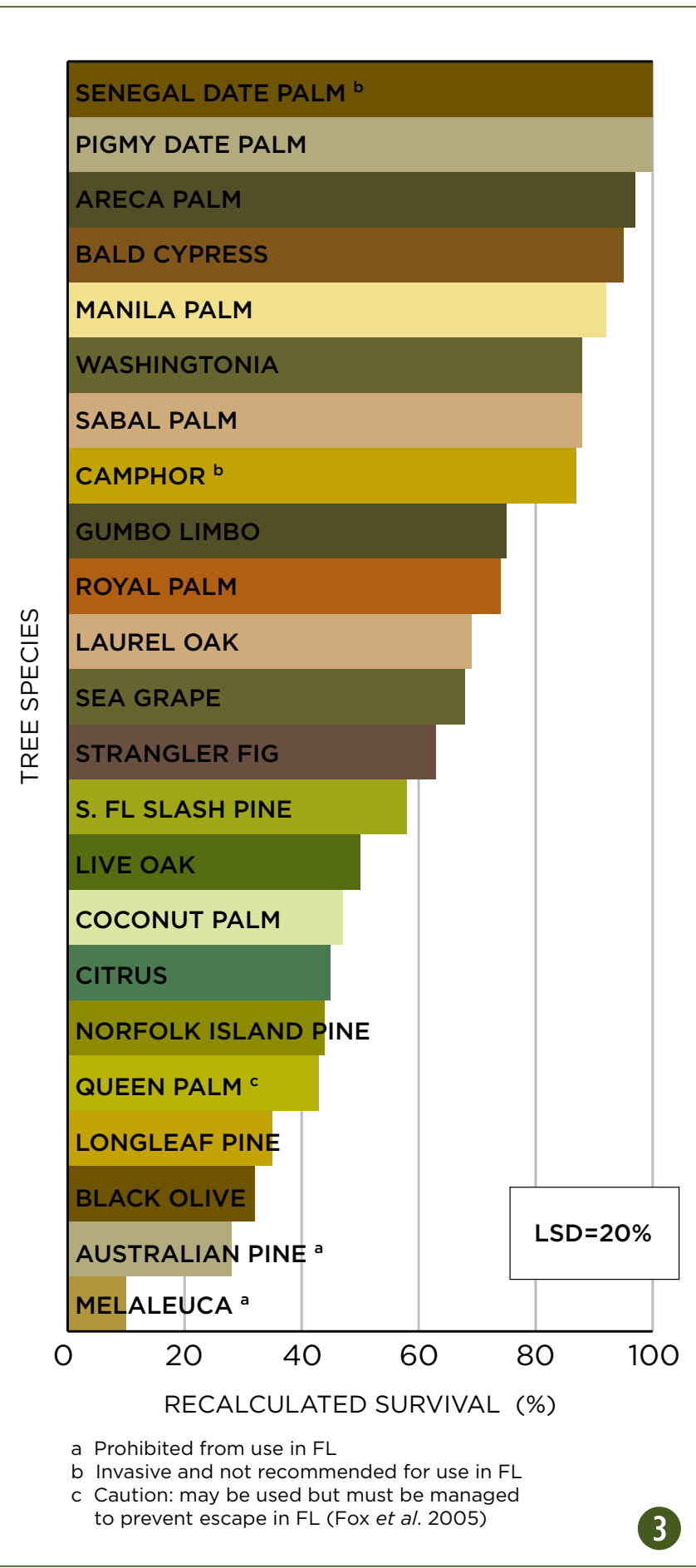

\section{Figure 3}

A recalculation of survival (\%) after considering trees with $\geq$ $50 \%$ branch loss as dead after Hurricane Charley.

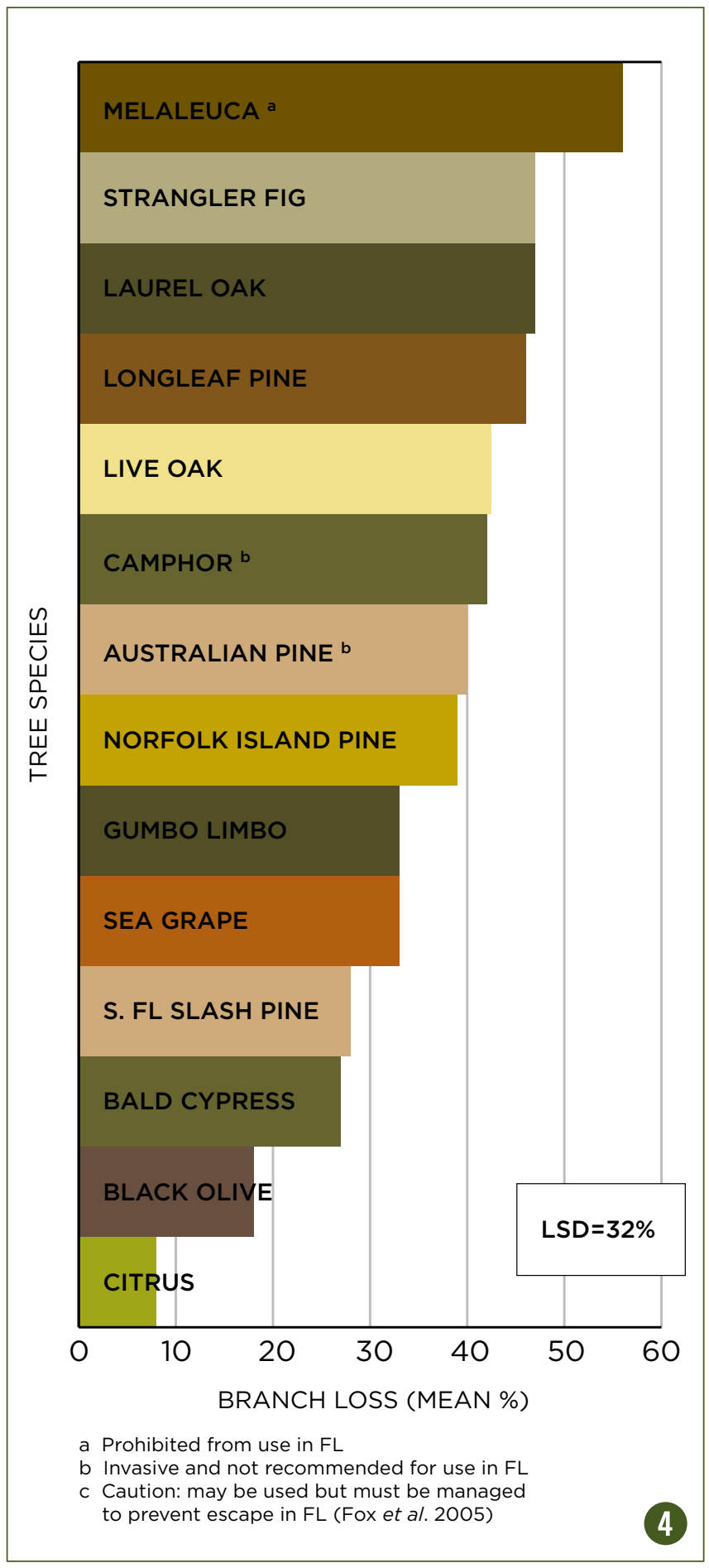

\section{Figure 4}

Branch loss (\%) for each tree species in Hurricane Charley, which struck land at $233 \mathrm{~km} / \mathrm{h}$ (130 $\mathrm{mph})$. 
Wind Resistance). However in the two south Florida hurricanes, both survival and branch loss for live and laurel oaks were similar (Figures 3 and 4). We also compared large trees of these species (greater than 50 $\mathrm{cm}$ diameter) and found that their survival, branch loss, and re-calculated survival were not significantly different in Jeanne and Charley (Figure 5).

Speculations about the reasons for lack of difference between live oak and laurel oak in south Florida include: (1) Laurel oak in south Florida may be a different cultivar or variety than those in north Florida and (2) sandier soils in south Florida and their accompanying lower site quality may result in laurel oaks with shorter heights or lower height-to-diameter ratio (as occurs between the north Florida and south Florida varieties of slash pine (Pinus elliottii var. elliottii and var. densa). Still, many authors point to live oak as a tree with strong wood and little failure in hurricanes (Touliatos and Roth 1971; Swain 1979; Hook et al. 1991; Barry et al. 1993).

\section{Conifers}

Of the conifer species, baldcypress survived Hurricane Charley the best with 95\% survival (Figure 1).

Baldcypress also suffered little damage after Hurricane Hugo (Putz and Sharitz 1991; Gresham et al. 1991).

After Hurricane Andrew, cypress trees in the Everglades National Park were still standing on the edges of the hammocks while many hardwoods had failed (Orr and Ogden 1992). Only 4\% of the sand pine (Pinus clausa) survived Hurricane Jeanne; sand pine's poor survival has been measured in several other hurricanes (Duryea 1997; Duryea et al. 2007a). South Florida slash pine is next best in wind resistance for the conifers across the south Florida hurricanes (Figure 6) but longleaf pine (Pinus palustris), which is usually similar to slash pine in wind resistance in the coastal plain hurricanes (Duryea et al. 2007a), had 57\% survival in Hurricane Charley. Survival of south Florida slash pine in pine rockland ecosystems ranged from 78 to $88 \%$ in Hurricane Andrew. Mortality of the standing pine trees continued for one year with 17 to $25 \%$ dying (Platt et al. 2000). We returned three months after Hurricane Charley and found that $27 \%$ of the standing south Florida slash pines and $48 \%$ of the standing longleaf pines had died.

\section{Puerto Rico Species}

Of the species measured in Puerto Rico, the species with the highest survival and least branch damage were Santa Maria (Calophyllum calaba), Caribbean pine, schefflera, West Indian mahogany, and Oriental arborvitae (Thuja orientalis) (Table 2 ).

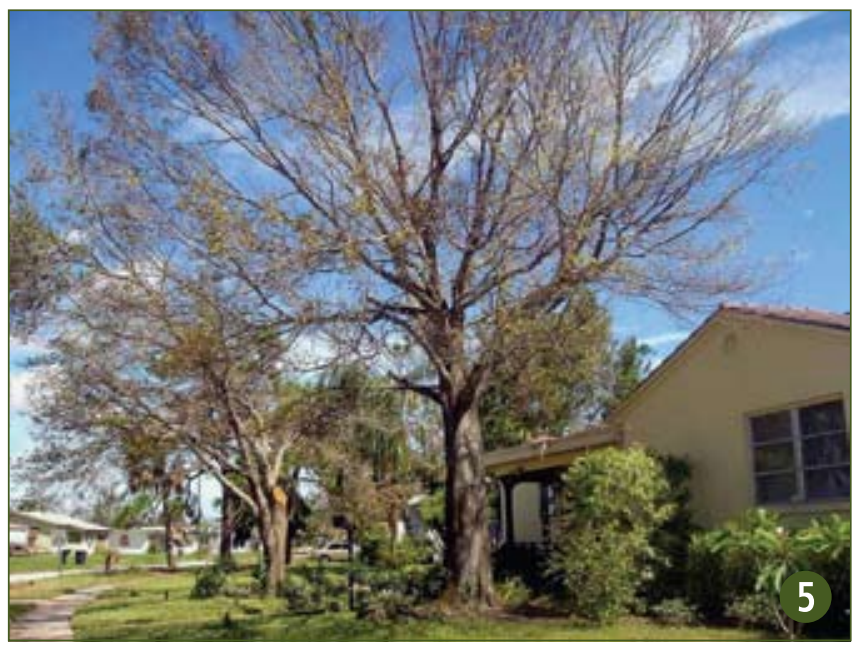

\section{Figure 5}

When compared to live oaks, laurel oaks in south Florida (above) showed no statistical difference for either survival, branch loss or re-calculated survival in hurricanes Charley and Jeanne.

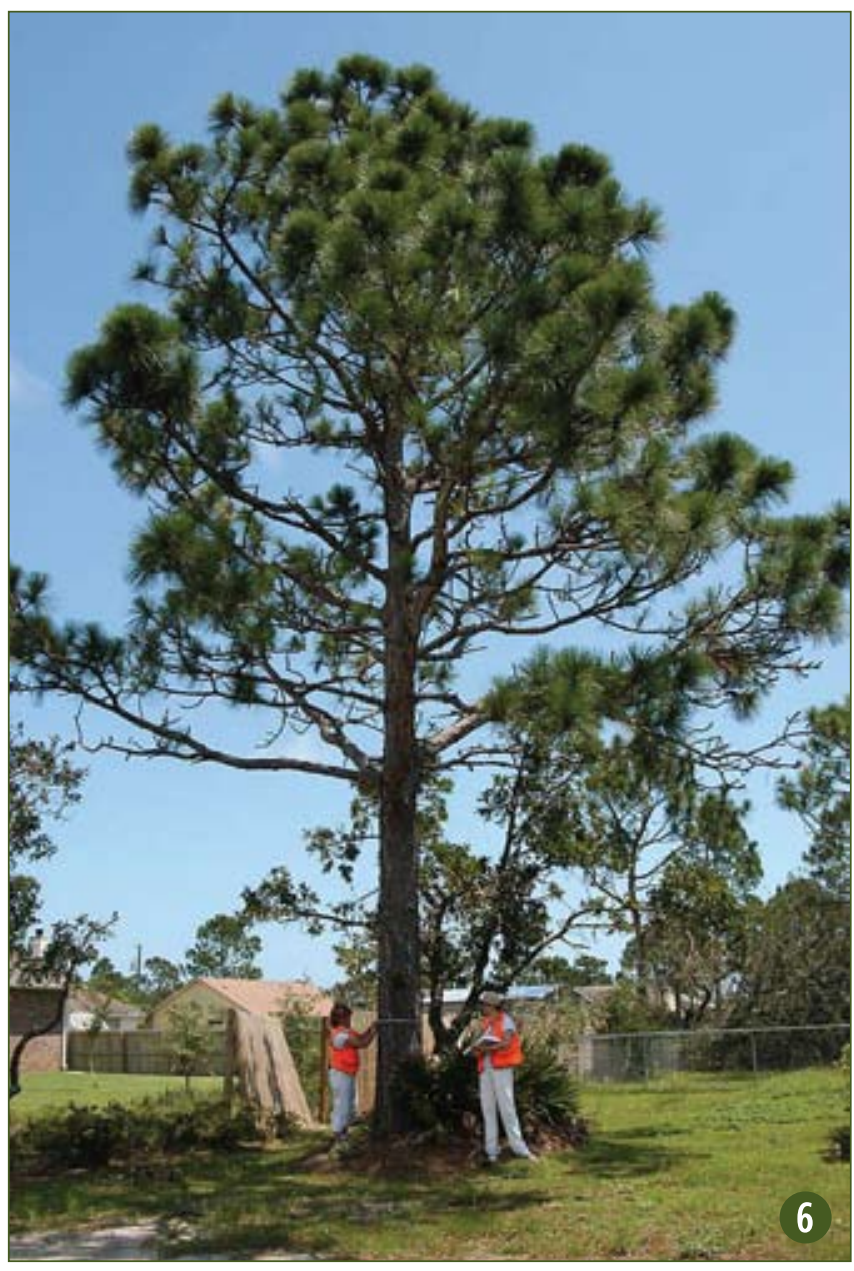

Figure 6

South Florida slash pine had $79 \%$ survival rate after Hurricane Charley. 
Table 2. Survival and branch loss of tree species in Puerto Rico after Hurricane Georges (110 mph).*

\begin{tabular}{|c|c|c|c|c|}
\hline Tree Species & Sample Size & Survival (\%) & Branch Loss (\%) & $\begin{array}{l}\text { Re-calculated } \\
\text { Survival } \\
\text { (\%) }\end{array}$ \\
\hline Araucaria heterophylla & 25 & 88 & 41 & 52 \\
\hline Bauhinia monandra & 31 & 71 & 41 & 39 \\
\hline Bucida buceras & 286 & 84 & 33 & 59 \\
\hline Callistemon citrinus & 42 & 81 & 12 & 69 \\
\hline Calophyllum calaba c (in S. FL) & 295 & 93 & 20 & 81 \\
\hline Cassia javanica & 28 & 86 & 42 & 57 \\
\hline Cassia siamea & 94 & 85 & 53 & 30 \\
\hline Crescentia cujete & 21 & 67 & 12 & 62 \\
\hline Cupressus sempervirens & 31 & 29 & 7 & 29 \\
\hline Delonix regia C (in S. FL) & 194 & 94 & 33 & 68 \\
\hline Enterolobium cyclocarpum & 20 & 100 & 23 & 85 \\
\hline Eucalyptus robusta & 69 & 86 & 59 & 28 \\
\hline Ficus benjamina & 65 & 83 & 25 & 63 \\
\hline Ficus macrocarpa & 33 & 76 & 18 & 67 \\
\hline Ficus microcarpa c (in C. \& S. FL) & 22 & 100 & 25 & 73 \\
\hline Hibiscus elatus & 25 & 100 & 63 & 20 \\
\hline Lagerstroemia speciosa & 138 & 88 & 28 & 70 \\
\hline Mangifera indica & 76 & 76 & 36 & 51 \\
\hline Melaleuca quinquenervia a & 37 & 65 & 21 & 57 \\
\hline Melicoccus bijugatus & 22 & 82 & 25 & 64 \\
\hline Pinus caribaea & 53 & 89 & 16 & 85 \\
\hline Pterocarpus indicus & 32 & 97 & 29 & 75 \\
\hline Pterocarpus macrocarpus & 43 & 95 & 33 & 77 \\
\hline Schefflera actinophylla b (in C. \& S. FL) & 24 & 88 & 17 & 79 \\
\hline Spathodea campanulata & 24 & 67 & 52 & 37 \\
\hline Swietenia mahagoni & 146 & 92 & 21 & 80 \\
\hline Swietenia macrophylla & 69 & 74 & 28 & 64 \\
\hline Swietenia macrophylla $\mathrm{x}$ mahagoni & 36 & 89 & 43 & 58 \\
\hline Tabebuia heterophylla & 334 & 83 & 26 & 65 \\
\hline Terminalia cattapa c (in S. FL) & 44 & 89 & 35 & 52 \\
\hline Thuja orientalis & 36 & 92 & 16 & 86 \\
\hline Least Significant Difference, $p=0.05$ & - & 16 & 21 & 23 \\
\hline $\begin{array}{l}\text { Prohibited from use in Florida } \\
\text { Invasive and not recommended for use in } \mathrm{FI} \\
\text { Caution: may be used but must be managed }\end{array}$ & nt escape in Flor & ox et al. 2005) & & \\
\hline
\end{tabular}


Many trees had extensive branch loss that reduced survival further with the most notable species being Norfolk Island pine (Araucaria heterophylla), Napoleon's plume (Bauhinia monandra), apple blossom (Cassia javanica), yellow cassia (Cassia siamea), swamp mahogany, mahoe (Hibiscus elatus) and African tuliptree. The twenty-four tree species measured in Francis' study (2000) following Hurricane Georges also showed extensive branch damage ranging from $23 \%$ to $81 \%$. Similar to our study, Francis also found that West Indian mahogany was the best survivor (100\% survival) and had the least branch loss while African tuliptree suffered the most crown loss and was one of the poorest survivors (66\% survival) (Francis 2000). Results for black olive and royal poinciana were also similar to those in our study, with trees surviving well (98\%) but losing nearly half of their branches.

\section{Native and Exotic Species}

Native tree species survived better in Hurricanes Jeanne, Charley, and Andrew but not in Hurricane Georges (Figure 7).

Native species also lost fewer branches than exotic species in Jeanne (21\% versus $36 \%, \mathrm{p}=0.0001)$ and Charley (36\% versus 39\%, $p=0.0001$ ). Some of the exotic species with low survival were melaleuca, Australian pine, and queen palm and these can be compared to native species with high survival - live oak, gumbo limbo, and sabal palm. In their extensive review of hurricanes and forest damage, Everham and Brokaw (1996) summarize that there is a trend towards more damage in exotic forest plantations although they also point out that these exotic forests are often monocultures. Out of the thirty-five tree species measured after Hurricane Georges in Puerto Rico $(\mathrm{n} \geq 20)$, only four were native trees to Puerto RicoSanta Maria, black olive, white cedar, and common calabash tree (Crescentia cujete). Santa Maria survived very well (93\%) but the other three had 84\%, 83\%, and $67 \%$ respectively, not surviving better than many of the exotic species (Table 2). Branch loss of exotics and natives in Puerto Rico, too, appeared to be equal (31\% for exotics versus $27 \%$, not statistically significant). With few exotic species in the urban forest population, natives also did not survive better in the southeastern U.S. coastal plain during Hurricane Ivan.

\begin{tabular}{|l|c:l|}
\hline \multicolumn{2}{|l|}{ FOR MORE INFORMATION " } \\
\hline $\begin{array}{l}\text { ON SURVIVAL RATES DURING } \\
\text { HURRICANE IVAN }\end{array}$ & $\mathbf{8}$ & $\begin{array}{l}\text { Selecting Southeastern Coastal } \\
\text { Plain Tree Species for Wind } \\
\text { Resistance }\end{array}$ \\
\hline
\end{tabular}

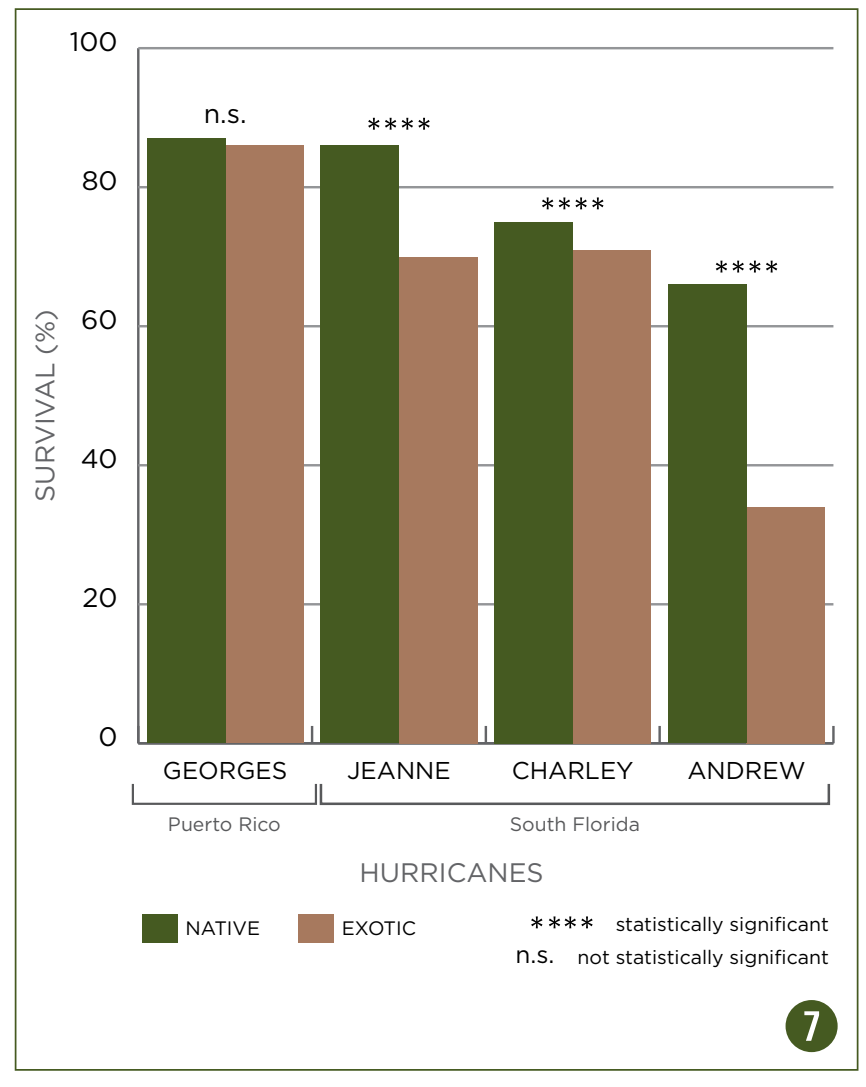

\section{Figure 7}

Native trees survived better than exotic trees in three South Florida hurricanes but not in Puerto Rico.

\section{The Survey}

Arborists, urban foresters, and scientists confirmed many of our results about wind resistance but also provided some new information about some species not so frequently seen and measured in the urban forest. Consistent with our results, queen palm was ranked by the experts as the palm with the lowest wind resistance (Table 3). Royal palm and coconut palm were intermediate, again consistent with our results. Sabal palm was ranked high, which is consistent with our results from the tropical and northern areas of Florida (Duryea 1996; Duryea 1997; Duryea et al. 2007a). Some of the species with little information from our studies that were ranked high by the experts include pond apple (Annona glabra), cocoplum (Chrysobalanus icaco), and lignum vitae (Guaiacum sanctum). Species with little research information that were ranked with low wind resistance include weeping banyan, jacaranda (Jacaranda mimosifolia), and golden trumpet (Tabebuia chrysotricha). Species ranked with high wind resistance in agreement with our results were crape myrtle (Lagerstroemia indica), dahoon holly (Ilex cassine), southern magnolia 
Table 3. Survey results for wind resistance of tropical and subtropical tree species.*

\begin{tabular}{|c|c|c|c|c|c|c|c|c|c|}
\hline \multirow{3}{*}{ Scientific Name } & \multirow{3}{*}{ Common Name } & \multicolumn{6}{|c|}{ Wind Resistance } & \multirow{3}{*}{ p-value } & \multirow{3}{*}{ Total N } \\
\hline & & \multicolumn{2}{|c|}{ High } & \multicolumn{2}{|c|}{ Medium } & \multicolumn{2}{|c|}{ Low } & & \\
\hline & & $\mathbf{N}$ & $\%$ & $\mathbf{N}$ & $\%$ & $\mathbf{N}$ & $\%$ & & \\
\hline Acer rubrum & red maple & 12 & 20 & 32 & 52 & 17 & 28 & 0.0049 & 61 \\
\hline Annona glabra & pond apple & 10 & 71 & 4 & 29 & 0 & 0 & n.s. & 14 \\
\hline Araucaria heterophylla & Norfolk Island pine & 8 & 18 & 14 & 31 & 23 & 51 & 0.0224 & 45 \\
\hline Averrhoa carambola & star-fruit or carambola & 3 & 18 & 6 & 35 & 8 & 47 & n.s. & 17 \\
\hline Bauhinia blakeana & Hong Kong orchid & 1 & 5 & 9 & 41 & 12 & 54 & 0.0122 & 22 \\
\hline Bucida buceras & black olive & 8 & 30 & 14 & 52 & 5 & 18 & 0.0538 & 27 \\
\hline Bursera simarouba & gumbo limbo & 21 & 64 & 10 & 30 & 2 & 6 & 0.0007 & 33 \\
\hline Callistemon spp & bottlebrush & 8 & 21 & 23 & 61 & 7 & 18 & 0.0018 & 38 \\
\hline Calophyllum calaba c (in S. FL) & Brazilian beautyleaf & 6 & 38 & 8 & 50 & 2 & 12 & n.s. & 16 \\
\hline Cassia fistula & golden shower & 4 & 18 & 7 & 32 & 11 & 50 & n.s. & 22 \\
\hline Ceiba (or Chorisia) speciosa & floss-silk & 4 & 18 & 12 & 55 & 6 & 27 & 0.0498 & 22 \\
\hline Chrysobalanus icaco & cocoplum & 18 & 78 & 5 & 22 & 0 & 0 & 0.0067 & 23 \\
\hline Chrysophyllum oliviforme & satinleaf & 11 & 61 & 7 & 39 & 0 & 0 & n.s. & 18 \\
\hline Citrus spp. & citrus (lime, orange, etc.) & 18 & 44 & 18 & 44 & 5 & 12 & 0.0162 & 41 \\
\hline Coccoloba diversifolia & pigeon plum & 11 & 58 & 8 & 42 & 0 & 0 & n.s. & 19 \\
\hline Coccoloba uvifera & sea grape & 18 & 50 & 12 & 33 & 6 & 17 & 0.0498 & 36 \\
\hline Conocarpus erectus & buttonwood & 11 & 35 & 17 & 55 & 3 & 10 & 0.0084 & 31 \\
\hline Cordia sebestena & geiger tree & 8 & 33 & 13 & 54 & 3 & 12 & 0.0439 & 24 \\
\hline x Cupressocyparis leylandii & leyland cypress & 7 & 22 & 13 & 41 & 12 & 37 & n.s. & 32 \\
\hline Delonix regia C (in S. FL) & royal poinciana & 2 & 6 & 20 & 63 & 10 & 31 & 0.0005 & 32 \\
\hline Enterolobium cyclocarpum & ear tree & 1 & 5 & 7 & 33 & 13 & 62 & 0.0058 & 21 \\
\hline Eriobotrya japonica C (in S. \& C. FL) & loquat & 9 & 24 & 24 & 63 & 5 & 13 & 0.0004 & 38 \\
\hline Eucalyptus cinerea & silver dollar eucalyptus & 2 & 13 & 9 & 56 & 5 & 31 & n.s. & 16 \\
\hline Eugenia axillaris & white stopper & 7 & 64 & 3 & 27 & 1 & 9 & n.s. & 11 \\
\hline Eugenia foetida & boxleaf, Spanish stopper & 7 & 64 & 2 & 18 & 2 & 18 & n.s. & 11 \\
\hline Ficus aurea & strangler fig & 4 & 36 & 5 & 46 & 2 & 18 & n.s. & 11 \\
\hline Ficus benjamina & weeping banyan & 0 & 0 & 2 & 18 & 9 & 82 & 0.0348 & 11 \\
\hline Grevillea robusta & silk oak & 1 & 4 & 8 & 32 & 16 & 64 & 0.0012 & 25 \\
\hline Guaiacum sanctum & lignumvitae & 10 & 83 & 2 & 17 & 0 & 0 & 0.0209 & 12 \\
\hline Ilex cassine & dahoon holly & 35 & 76 & 10 & 22 & 1 & 2 & 0.0001 & 46 \\
\hline Jacaranda mimosifolia & jacaranda, black poui & 1 & 7 & 2 & 13 & 12 & 80 & 0.0006 & 15 \\
\hline Juniperus silicicola & SE red cedar & 14 & 28 & 18 & 35 & 19 & 37 & n.s. & 51 \\
\hline Kigelia pinnata & sausage tree & 7 & 41 & 6 & 35 & 4 & 24 & n.s. & 17 \\
\hline Koelreuteria paniculata & golden raintree & 11 & 37 & 11 & 37 & 8 & 26 & n.s. & 30 \\
\hline Krugiodendron ferreum & ironwood & 10 & 77 & 3 & 23 & 0 & 0 & n.s. & 13 \\
\hline Lagerstroemia indica & crape myrtle & 55 & 83 & 11 & 17 & 0 & 0 & 0.0001 & 66 \\
\hline
\end{tabular}


(Table 3 continued)

\begin{tabular}{|c|c|c|c|c|c|c|c|c|c|}
\hline \multirow{3}{*}{ Scientific Name } & \multirow{3}{*}{ Common Name } & \multicolumn{6}{|c|}{ Wind Resistance } & \multirow{3}{*}{ p-value } & \multirow{3}{*}{ Total $\mathbf{N}$} \\
\hline & & \multicolumn{2}{|c|}{ High } & \multicolumn{2}{|c|}{ Medium } & \multicolumn{2}{|c|}{ Low } & & \\
\hline & & $\mathbf{N}$ & $\%$ & $\mathbf{N}$ & $\%$ & $\mathbf{N}$ & $\%$ & & \\
\hline Ligustrum japonicum & privet & 30 & 75 & 9 & 23 & 1 & 2 & 0.0001 & 40 \\
\hline Liquidambar styraciflua & sweetgum & 19 & 43 & 22 & 50 & 3 & 7 & 0.0013 & 44 \\
\hline Litchi chinensis & lichee & 8 & 57 & 5 & 36 & 1 & 7 & n.s. & 14 \\
\hline Lysiloma latisiliqua & wild tamarind & 9 & 50 & 6 & 33 & 3 & 17 & n.s. & 18 \\
\hline Magnolia grandiflora & SE magnolia & 45 & 82 & 9 & 16 & 1 & 2 & 0.0001 & 55 \\
\hline Mangifera indica & mango tree & 6 & 20 & 16 & 53 & 8 & 27 & n.s. & 30 \\
\hline Peltophorum pterocarpa & yellow poinciana & 1 & 5 & 15 & 68 & 6 & 27 & 0.0010 & 22 \\
\hline Persea americana & avocado tree & 1 & 3 & 20 & 63 & 11 & 34 & 0.0002. & 32 \\
\hline Pinus clausa & sand pine & 3 & 7 & 7 & 16 & 34 & 77 & 0.0001 & 44 \\
\hline Pinus elliottii var. densa & FL slash pine & 18 & 38 & 25 & 52 & 5 & 10 & 0.0016 & 48 \\
\hline Pinus palustris & longleaf pine & 23 & 56 & 13 & 32 & 5 & 12 & 0.0017 & 41 \\
\hline Podocarpus spp. & podocarpus & 24 & 75 & 7 & 22 & 1 & 3 & 0.0001 & 32 \\
\hline Prunus caroliniana & carolina laurel cherry & 5 & 16 & 15 & 48 & 11 & 36 & n.s. & 31 \\
\hline Quercus geminata & sand live oak & 36 & 92 & 2 & 5 & 1 & 3 & 0.0001 & 39 \\
\hline Quercus laurifolia & laurel oak & 3 & 4 & 27 & 39 & 39 & 57 & 0.0001 & 69 \\
\hline Quercus nigra & water oak & 3 & 8 & 14 & 36 & 22 & 56 & 0.0009 & 39 \\
\hline Quercus stellata & post oak & 5 & 33 & 10 & 67 & 0 & 0 & n.s. & 15 \\
\hline Quercus virginiana & live oak & 64 & 89 & 8 & 11 & 0 & 0 & 0.0001 & 72 \\
\hline Sideroxylon foetidissimum & mastic tree & 3 & 30 & 6 & 60 & 1 & 10 & n.s. & 10 \\
\hline Simarouba glauca & paradise tree & 5 & 42 & 5 & 42 & 2 & 16 & n.s. & 12 \\
\hline Spathodea campanulata & African tuliptree & 0 & 0 & 6 & 38 & 10 & 62 & n.s. & 16 \\
\hline Swietenia mahagoni & West Indian mahagony & 2 & 9 & 13 & 56 & 8 & 35 & n.s. & 23 \\
\hline Tabebuia aurea & silver trumpet & 0 & 0 & 4 & 33 & 8 & 67 & n.s. & 12 \\
\hline Tabebuia chrysotricha & golden trumpet & 2 & 7 & 5 & 18 & 21 & 75 & 0.0001 & 28 \\
\hline Tabebuia heterophylla & white cedar & 0 & 0 & 6 & 55 & 5 & 45 & n.s. & 11 \\
\hline Tabebuia impetiginosa & purple tabebuia, ipe & 3 & 12 & 12 & 50 & 9 & 38 & n.s. & 24 \\
\hline Tecoma stans & yellow elder & 0 & 0 & 8 & 73 & 3 & 27 & n.s. & 11 \\
\hline Terminalia catappa c (in S. FL) & tropical almond & 3 & 20 & 8 & 53 & 4 & 27 & n.s. & 15 \\
\hline Taxodium distichum & baldcypress & 59 & 91 & 6 & 9 & 0 & 0 & 0.0001 & 65 \\
\hline Taxodium ascendens & pondcypress & 41 & 91 & 4 & 9 & $\mathrm{O}$ & 0 & 0.0001 & 45 \\
\hline \multicolumn{10}{|c|}{ Palms } \\
\hline Butia capitata & pindo & 34 & 79 & 7 & 16 & 2 & 5 & 0.0001 & 43 \\
\hline Caryota mitis & fishtail & 8 & 38 & 6 & 29 & 7 & 33 & n.s. & 21 \\
\hline Chrysalidocarpus lutescens & areca & 19 & 63 & 11 & 37 & 0 & 0 & n.s. & 30 \\
\hline Coccothrinax argentata & FL silver, silver thatch & 21 & 95 & 1 & 5 & 0 & 0 & 0.0001 & 22 \\
\hline Cocos nucifera & coconut & 22 & 63 & 13 & 37 & 0 & 0 & n.s. & 35 \\
\hline
\end{tabular}


(Table 3 continued)

\begin{tabular}{|c|c|c|c|c|c|c|c|c|c|}
\hline \multirow{3}{*}{ Scientific Name } & \multirow{3}{*}{ Common Name } & \multicolumn{6}{|c|}{ Wind Resistance } & \multirow{3}{*}{ p-value } & \multirow{3}{*}{ Total $\mathbf{N}$} \\
\hline & & \multicolumn{2}{|c|}{ High } & \multicolumn{2}{|c|}{ Medium } & \multicolumn{2}{|c|}{ Low } & & \\
\hline & & $\mathbf{N}$ & $\%$ & $\mathbf{N}$ & $\%$ & $\mathbf{N}$ & $\%$ & & \\
\hline Hyophorbe lagenicaulis & bottle & 13 & 81 & 3 & 19 & 0 & 0 & 0.0124 & 16 \\
\hline Hyophorbe verschaffeltii & spindle & 11 & 79 & 2 & 14 & 1 & 7 & 0.0015 & 14 \\
\hline Latania loddigesii & blue latan & 8 & 67 & 3 & 25 & 1 & 8 & 0.0388 & 12 \\
\hline Livistona chinensis C (in S. \& C. FL) & chinese fan & 29 & 71 & 9 & 22 & 3 & 7 & 0.0001 & 41 \\
\hline Neodypsis decaryi & triangle & 14 & 58 & 6 & 25 & 4 & 17 & 0.0302 & 24 \\
\hline Phoenix canariensis & Canary Island date & 49 & 89 & 4 & 7 & 2 & 4 & 0.0001 & 55 \\
\hline Phoenix dactylifera & date & 33 & 94 & 2 & 6 & 0 & 0 & 0.0001 & 35 \\
\hline Phoenix reclinata $\mathrm{b}$ (in $\mathrm{S} . \mathrm{FL}$ ) & Senegal date & 29 & 85 & 5 & 15 & 0 & 0 & 0.0001 & 34 \\
\hline Phoenix roebelenii & pygmy date & 40 & 98 & 1 & 2 & 0 & 0 & 0.0001 & 41 \\
\hline Ptychosperma elegans & Alexander, solitary & 16 & 73 & 6 & 27 & 0 & 0 & 0.0330 & 22 \\
\hline Roystonea elata & Florida royal & 19 & 56 & 10 & 29 & 5 & 15 & 0.0118 & 34 \\
\hline Roystonea regia & Cuban royal & 17 & 61 & 10 & 36 & 1 & 4 & 0.0010 & 28 \\
\hline Sabal palmetto & cabbage & 71 & 99 & 1 & 1 & 0 & 0 & 0.0001 & 72 \\
\hline Syagrus romanzoffiana C (in S. FL) & queen & 5 & 10 & 17 & 33 & 29 & 57 & 0.0002 & 51 \\
\hline Thrinax morrisii & Key thatch & 13 & 87 & 2 & 13 & 0 & 0 & 0.0045 & 15 \\
\hline Thrinax radiata & Florida thatch & 17 & 89 & 2 & 11 & 0 & 0 & 0.0006 & 19 \\
\hline Veitchia merrillii & Manila, Christmas & 13 & 81 & 3 & 19 & 0 & 0 & 0.0124 & 16 \\
\hline Washingtonia robusta & Washington fan & 29 & 54 & 16 & 30 & 9 & 17 & 0.0033 & 54 \\
\hline \multicolumn{10}{|c|}{ Invasive and not recommended for use in Florida } \\
\hline \multicolumn{10}{|c|}{ Caution: may be used but must be managed to prevent escape in Florida (Fox et al. 2005) } \\
\hline
\end{tabular}

(Magnolia grandiflora), sand live oak, live oak, and both species of cypress (Taxodium distichum and T. ascendens). One perplexing species is West Indian mahogany, which fared reasonably well in Georges and Andrew (Table 1); however the survey respondents ranked it with medium to low wind resistance. In agreement with our results but in contrast to the survey results, in another study of twenty-four species experiencing Hurricane Georges, West Indian mahogany had the best survival and the least branch loss (Francis 2000).

\section{Recommendations}

Taking the results from our studies and incorporating the survey results and the scientific literature, we have developed lists of relative wind resistance for tropical and subtropical tree species (Table 4). These lists should be used with caution, with the knowledge that no species and no tree is completely wind proof, and with the consideration of local soil conditions, tree age, structure and health, and other urban forest conditions. In their thorough review of forest damage from wind, Everham and Brokaw (1996) concluded that species differences do exist and can be explained by differences in wood density, canopy architecture, rooting patterns, susceptibility to diseases and bole shape. Yet these differences, they say, can also be masked by varied soil conditions, exposure, wind intensity, and cultural practices. 
Table 4. Wind resistance of tropical and subtropical tree species.*

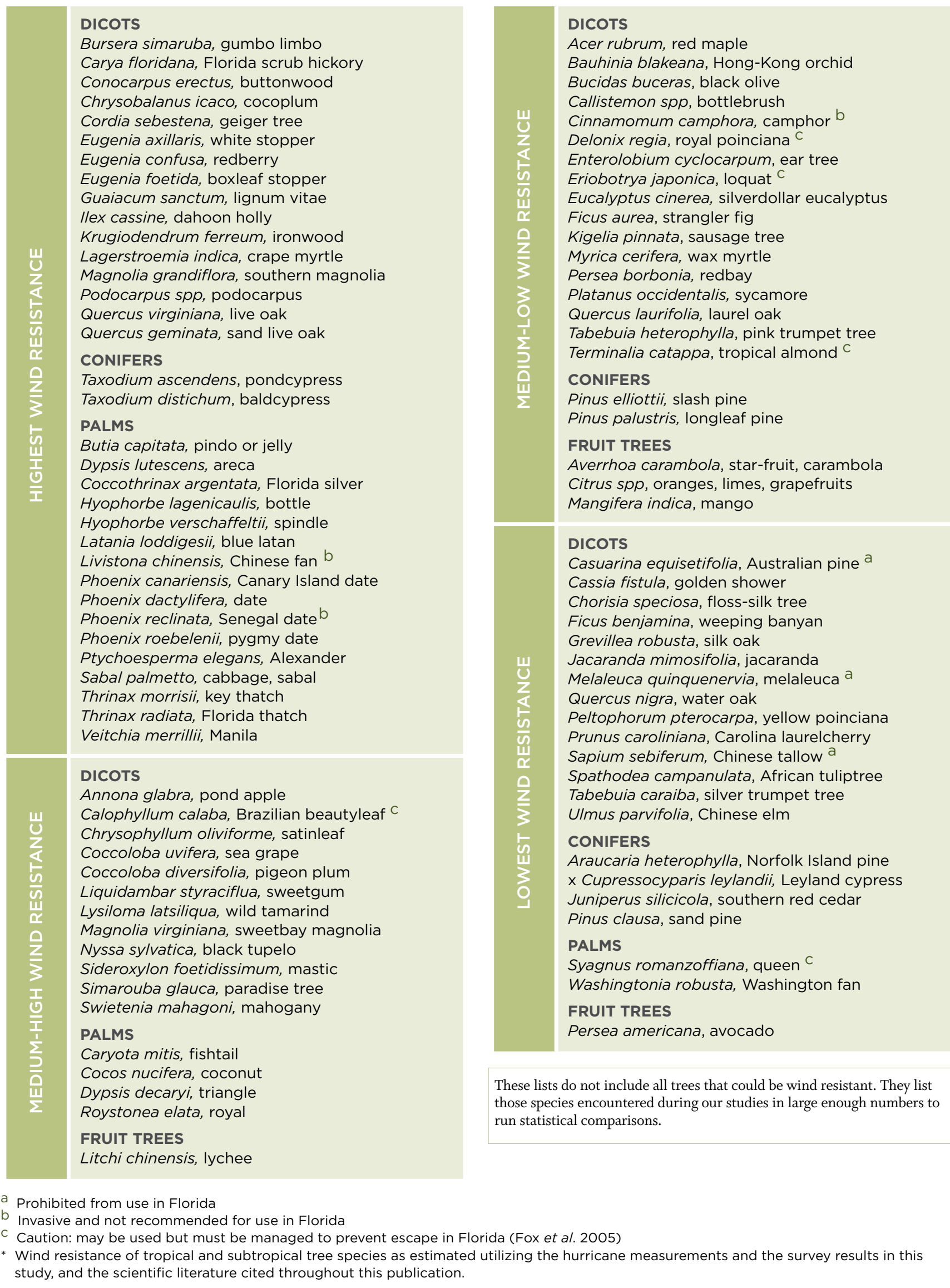




\section{Important Recommendations}

Some significant findings from this study reported in Chapter 5-Lessons Learned from Hurricanes:

One of the most important findings reported is the rooting space results: the more rooting space that a tree has, the healthier it is, meaning better anchorage and resistance to wind.

Another important cultural practice for broadleaved trees is pruning. Pruning conferred more wind resistance to trees and should be considered an important practice for tree health and wind resistance.

Trees growing in groups or clusters were also more wind resistant compared to individual trees. This might be an especially good strategy for tree establishment in parks or larger yards.

Especially in south Florida, native trees appear to survive winds better than exotics. When considering species to plant, know which exotic species do not fare well in wind-some of these include melaleuca, Australian pine, queen palm, African tulip tree, and weeping banyan.
Everham III, E.M. and N.V.L. Brokaw. 1996. Forest damage and recovery from catastrophic wind. The Botanical Review 62:113-185.

Fox, A.M., D.R. Gordon, J.A. Dusky, L. Tyson, and R.K. Stocker. 2005. IFAS assessment of the status of non-native plants in Florida's natural areas. SS-AGR-225 of the University of Florida IFAS Cooperative Extension Service.

http://plants.ifas.ufl.edu/assessment.html Gainesville, FL. 27 pp.

Francis, J. K. 200o. Comparison of hurricane damage to several species of urban trees in San Juan, Puerto Rico. J. Arboric. 26:189-197.

Francis, J.K. and A.J.R. Gillespie. 1993. Relating gust speed to tree damage in Hurricane Hugo, 1989. J. Arboric. 19:368-372.

Frangi, J.L. and A.E. Lugo. 1991. Hurricane damage to a flood plain forest in the Luquillo Mountains of Puerto Rico. Biotropica 23(4) (Part A. Special Issue: Ecosystem, Plant, And Animal Responses to Hurricanes in the Caribbean): 324-335.

Gresham, C.A., T.M. Williams, and D.J. Lipscomb. 1991. Hurricane Hugo wind damage to Southeastern U.S. coastal forest tree species. Biotropica 23(4) (Part A. Special Issue: Ecosystem, Plant, and Animal Responses to Hurricanes in the Caribbean):420-426.

Hook, D.D., M.A. Buford, and T.M. Williams. 1991. Impact of Hurricane Hugo on the South Carolina coastal plain forest. J. Coastal Res. (Special issue) 8:291-300.

Orr, D.W. and J.C. Ogden. 1992. The impact of Hurricane Andrew on the Ecosystems of South Florida. Conservation Biology 6(4):488-49o.

Platt, W.J. , R.F. Doren, and T.V. Armentano. 20oo. Effects of Hurricane Andrew on stands of slash pine (Pinus elliottii var. densa) in the everglades region of south Florida (USA). Plant Ecology 146:43-6o.

Putz, F.E., and R.R. Sharitz. 1991 Hurricane damage to oldgrowth forests in Congaree Swamp National Monument, South Carolina, U.S.A. Can. J. For. Res. 21:1765-1770.

Swain, K.M. 1979. Minimizing timber damage from hurricanes. S. Lumberman 239:107-109.

Touliatos, P. and E. Roth. 1971. Hurricanes and trees: Ten lessons from Camille. J. For. 285-289.

Zimmerman, J.K., E.M. Everham III, R.B. Waide, D.J. Lodge, C.M. Taylor, and N.V.L. Brokaw. 1994. Responses of tree species to hurricane winds in a subtropical wet forest in Puerto Rico: Implications for tropical tree life histories. Ecology 82:911-922.

\footnotetext{
This document is FOR 120, one of the Urban Forest Hurricane Recovery series of the School of Forest Resources and Conservation and the Environmental Horticulture Department, Florida Cooperative Extension Service, Institute of Food and Agricultural Sciences, University of Florida. Original publication date September 2007. Visit the EDIS Web Site at http://edis.ifas.ufl.edu and http://treesandhurricanes.ifas.ufl.edu.

Mary Duryea, Professor, School of Forest Resources and Conservation and Associate Dean for Research; Eliana Kampf, Urban Forester, School of Forest Resources and Conservation, University of Florida, Institute of Food and Agricultural Sciences, Gainesville, FL 32611.

Design and layout: Mariana Wallig \& Julie Walters.

The Institute of Food and Agricultural Sciences (IFAS) is an Equal Employment Opportunity-Affirmative Action Employer authorized to provide research, educational information and other services only to individuals and institutions that function without regard to race, creed, color, religion, age, disability, sex, sexual orientation, marital status, national origin, political opinions or affiliations. For information on obtaining other extension publications, contact your county Cooperative Extension Service office. Florida Cooperative Extension Service / Institute of Food and Agricultural Sciences / University of Florida / Larry R. Arrington, Dean.
} 